\title{
MORPHOLOGICAL STUDY ON LITTORINA FLAVA (KING \& BRODERIP) FROM BRAZIL (CAENOGASTROPODA, LITTORINIDAE)
}

\author{
Luiz Ricardo L. Simone ${ }^{1}$
}

\begin{abstract}
A detailed morphological study of the littorinid Littorina flava (King \& Broderip), from Venezuelan and Brazilian coasts, is given and commented. A considerable degree of shell characters variation was found, mainly in color and sculpture. The pallial cavity presents normal fashion of mesogastropods, without any detectable morphological modification for the long air-exposure. The digestive system present odontophore muscles very similar to those of the cerithioideans and hydrobioideans; the radula, however, is enormously long; the stomach lacks differentiable style sac. The penis is characteristic in lacking annex glands. The pallial oviduct has no jelly gland, and has a well developed bursa copulatrix and vaginal tube.

KEY WORDS. Mollusca, Littorina flava, morphology, systematics, Brazil
\end{abstract}

Littorina flava King \& Broderip, 1832 is one of the most common species of Brazilian coast, occurring in almost its entire supra tidal area. Although generally occurring on rocks of open sea or bays, sometimes L. flava is found also in estuarine environment (FURTADO-OGAWA 1975; RIOS 1994).

Some systematic studies on this species, and other Western Atlantic relatives, are found in literature (BEQUAERT 1943; BANDEL \& KADOLSKY 1982), and even some brief anatomical data (MARCUS \& MARCUS 1963). In the mean time, some systematic doubts still persist, one of them is the validity of the specific level of flava. Some authors consider it as valid species (MARCUS \& MARCUS 1963; RIOS 1994), others as subspecies of L. nebulosa (Lamarck, 1822) (BEQUAERT 1943; MATTHEWS 1968) while others as synonyms (ABBOTT 1974). The shell characters, the base for this discussion, apparently does not bear sufficient data for its solution. Maybe a deeper knowledge on the inner morphology of the species could bring a light, and a base for further comparisons.

This paper is part of a larger project of comparative morphology and phylogeny of some groups of Caenogastropoda, the littorinids were selected as one of the outgroups. L. flava, one of selected littorinids, was morphologically studied and a description of some characters is given complementing the upper cited papers.

\section{MATERIAL AND METHODS}

Detailed list of examined specimens follows species description. All examined lots are in the collection of the "Museu de Zoologia da Universidade de São Paulo" (MZSP) preserved in 70\% ethanol. A specimen from Venezuela and specimens of several places of Brazilian coast were selected for study.

1) Museu de Zoologia, Universidade de São Paulo. Caixa Postal 42694, 04299-970 São Paulo, São Paulo, Brasil.

e-mail: Irsimone@usp.br

Revta bras. Zool. 15 (4): 875 - 887, 1998 
The studied specimens were extracted from the shells and dissected by standard technique under stereomicroscope, with the specimen immerse under water. Some structures such as buccal mass and pallial gonoducts were dehydrated in ethanol series, stained in carmine, cleared and fixed in creosote. Radulae and opercula were also examined in SEM in the "Laboratório de Microscopia Eletrônica do Instituto de Biociências da Universidade de São Paulo". All drawings were made with the aid of a camera lucida. Measurements are in millimeters, and were obtained with the shell in frontal view.

In the figures, the following abbreviations are used: (aa) anterior aorta, (ag) albumen gland, (an)anus, (au) auricle, (bg) buccal ganglion, (bm) buccal mass, (br) subradular membrane, (bv) blood vessel or sinus, (ce) cerebral ganglion, (cg) capsule gland, (cm) columellar muscle, (cv) ctenidial vein, (dd) duct to digestive gland, (df) inner folds of dorsal wall of buccal mass, (dg) digestive gland, (dl) dorsal layer of transversal muscles of odontophore, (dp) dorsal projection of tissue covering radula, (ea) esophageal aperture, (ec) esophageal crop, (ef) esophageal fold, (eg) esophageal pouch, (es) esophagus, (ey) eye, (fa) female aperture, (gf) gastric fold, (gi) gill, (gl) glandiform structure of penis, (go) gonad, (gp) gonopericardial duct, (gs) gastric shield, (hg) hypobranchial gland, (in) intestine, (ir) insertion of $\mathrm{m} 4$ in tissue on radular ribbon, (is) insertion of $\mathrm{m} 5$ in radular ribbon, $(\mathbf{k m})$ membrane between kidney and pallial cavity, (m1 to $\mathbf{m} 10)$ odontophore muscles, (mb) mantle border, (mo) mouth, (ne) nephrostome, (nr) nerve ring, (oc) odontophoric cartilage, (op) operculum, (os) osphradium, (ov) oviduct, (pa) pleural ganglion, (pb) peribuccal muscles, (pd) pedal ganglion, (pe) penis, (pg) pedal gland anterior furrow, (po) pallial oviduct, (pt) prostate, (ra) radula, (rn) radular nucleus, (rs) radular sac, (rt) rectum, (sc) subradular cartilage, (sd) salivary gland duct, (se) salivary gland aperture, (sg) salivary gland, (sn) snout, (so, statocyst, (sr) seminal receptacle, (st) stomach, (su) supra-esophageal connective, (tr) tissue on middle region of radula, (up) union of $\mathrm{m} 5$ with its pair, (va) vaginal tube, (vd) vas deferens, (ve) ventricle, (vl) ventral layer of muscles of odontophore.

\section{RESULTS}

\section{Littorina flava King \& Broderip, 1832 Figs 1-34}

Littorina flava King \& Broderip, 1832: 345 [Rio de Janeiro]. -Orbigny, 1840: 391, pl. 53, f. 1-3. Morretes, 1949: 69. - Marcus \& Marcus, 1963: 6-7, f. 4, 10-11, 17-21, 26. - Vermeij \& Porter, 1971: 448. - Bandel, 1974: 162. - Rios, 1975: 33, pl. 9, f. 108. - 1985: 34, pl. 14, f. 145. - 1994: 49 , pl. 15 , f. 166.

Littorina nebulosa flava; Bequaert, 1943: 13-14, pl. 4, f. 5-7. - Matthews, 1968: 184. -Rios, 1970: 32-33. - Furtado-Ogawa, 1970: 194. - Oliveira et al., 1981: 83.

Littorina nebulosa; Abbott, 1974: 69 (part).

\section{Morphological description}

Shell (Figs 1-4). Of medium size (up to $20 \mathrm{~mm}$ ), globose; spire somewhat tall, sharp. Color pale cream (Figs 1-2), sometimes with sparse brown spots (Figs 3-4). Sculpture several spiral furrows uniformly spaced. Aperture rounded; outer lip simple, thick; inner lip glossy, with characteristic dark brown spot (Figs 1-3). Other details in BEQUAERT (1943: 13-14); MARCUS \& MARCUS (1963: 6-7). 

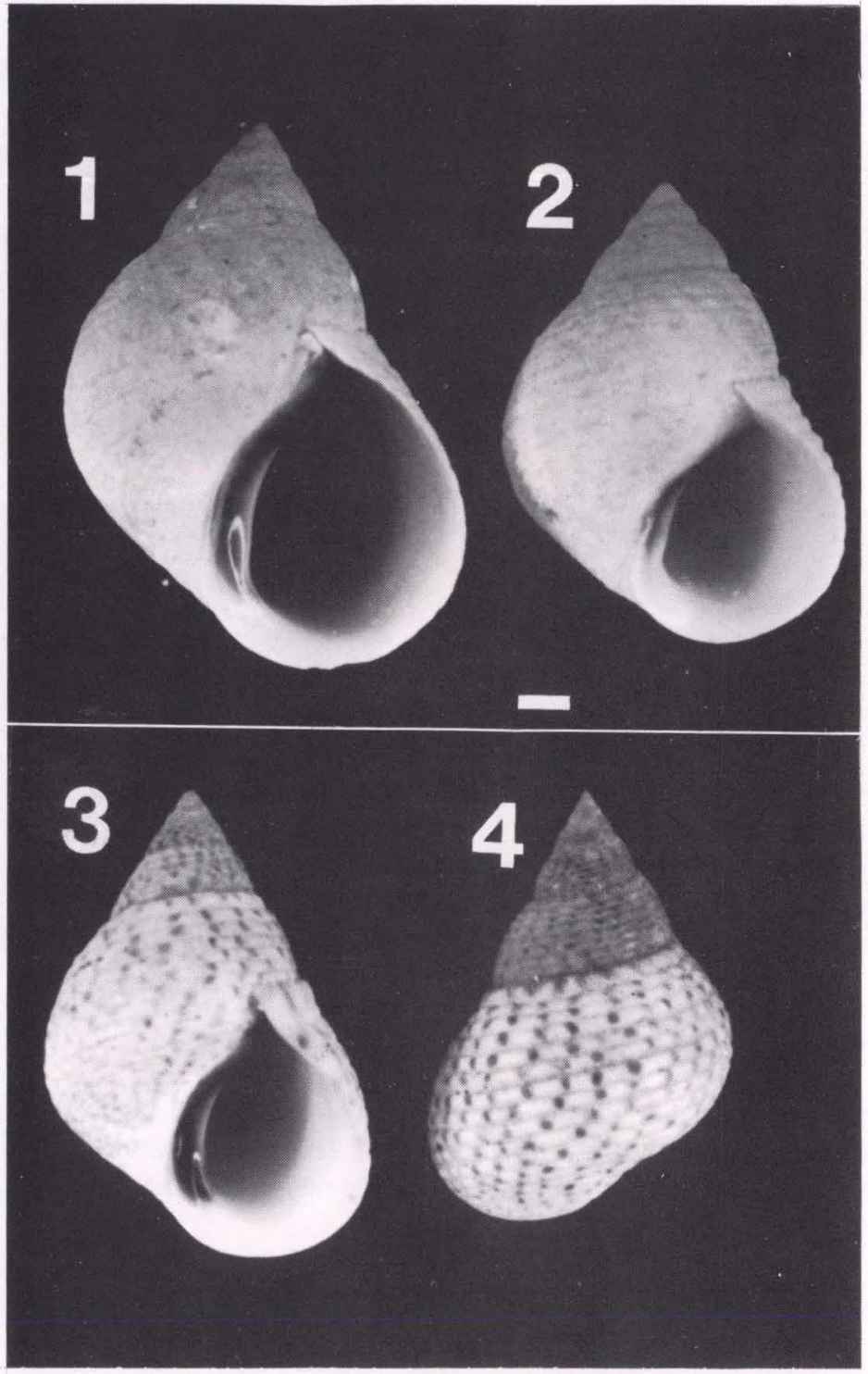

Figs 1-4. Littorina flava. (1-4) Shell variation, (1-2) specimens from Rio de Janeiro (MZSP 24859), (3-4) specimens from Bahia (MZSP 28308), scale $=2 \mathrm{~mm}$.

Head-foot. Color yellowish beige with dark brown spots, of imprecise limits, sparse in head, tentacles, snout and dorsal surface of foot. Head outstanding, broad (Figs 9-10). Snout short, cylindrical, rounded anterior margin; ventral-anterior surface somewhat plane, with a deep, central, longitudinal furrow where mouth sites (Fig. 15). Tentacles long, stubby, base very broader than middle region (Figs 9, 10, 

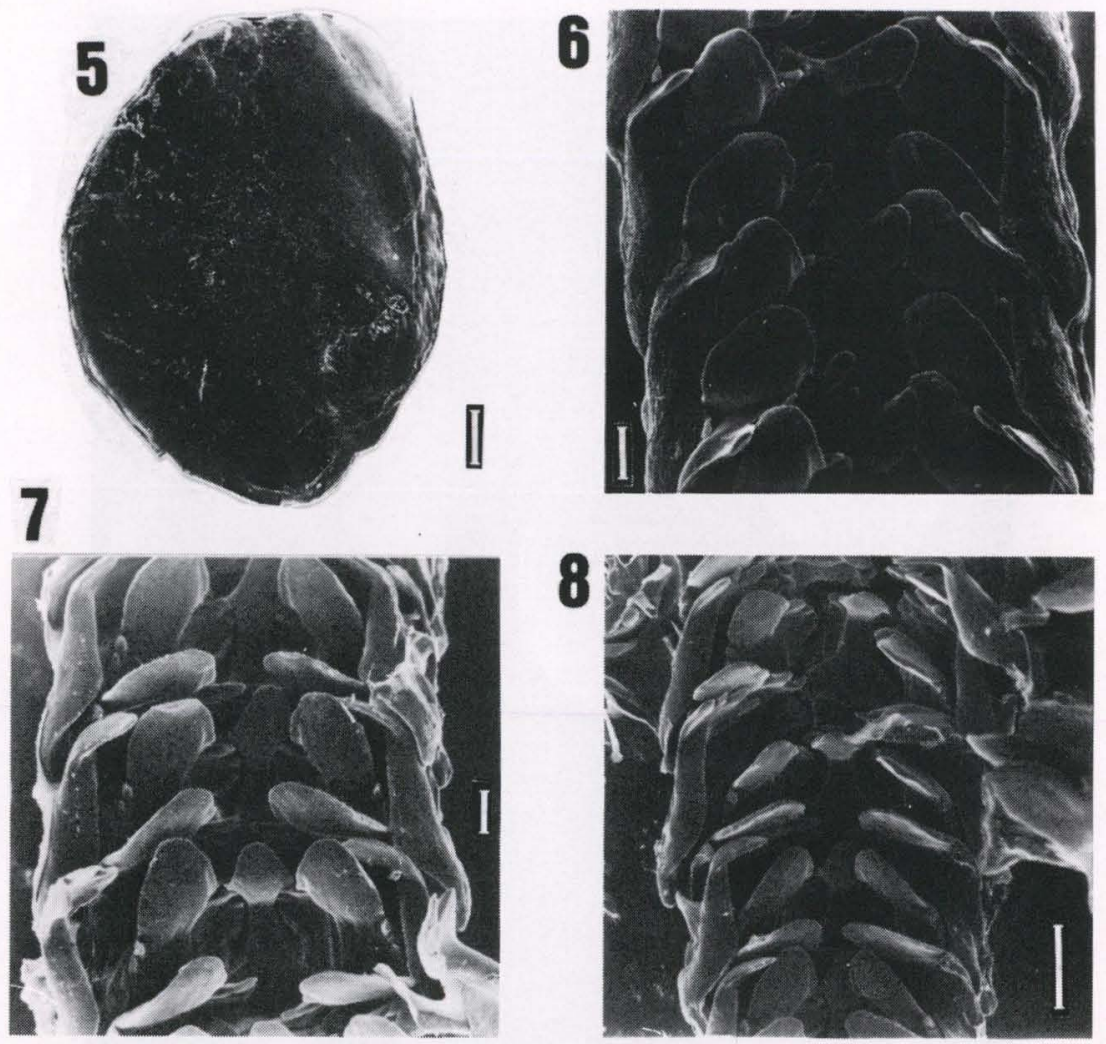

Figs 5-8. Littorina flava. (5) Operculum, outer view, SEM, scale $=0.5 \mathrm{~mm} ;(6-8)$ radula of different specimens, SEM, scales (6-7) $=20 \mu \mathrm{m},(8)=50 \mu \mathrm{m}$.

15). Eyes dark, sited on small ommatophores of proximal third of tentacles' external surface. Foot of medium size, without divisions; a furrow in anterior margin of pedal glands (Figs 9, 10). Males with penis in right region of head described bellow. Columellar muscle of about one whorl.

Operculum (Fig. 5). Subcircular, corneous, subcentral nucleus, palcispiral, thin; brown transparent. Scar broad, near inner margin. Occupies entire aperture.

Mantle organs (Figs 11, 13). Mantle border simple, thick, without developed appendices nor siphon; pale cream in color. Pallial cavity of little more than half whorl. Osphradium long, ridge-like, lying left margin of pallial cavity at about half of gill length; anterior extremity of osphradium posterior to that of gill. Gill elliptical, with about same length than pallial cavity; broad, with both extremities narrowing suddenly; bears many filaments broad, triangular, low; tip of each filament sharp pointed, of somewhat central position, turned to right. Ctenidial vein well-developed, somewhat uniform width. Between gill and rectum a narrow area. Hypobranchial gland low, more developed in posterior $2 / 3$ of area between gill and rectum, with several transversal chambers. Ad-rectal sinus and afferent gill vessel 

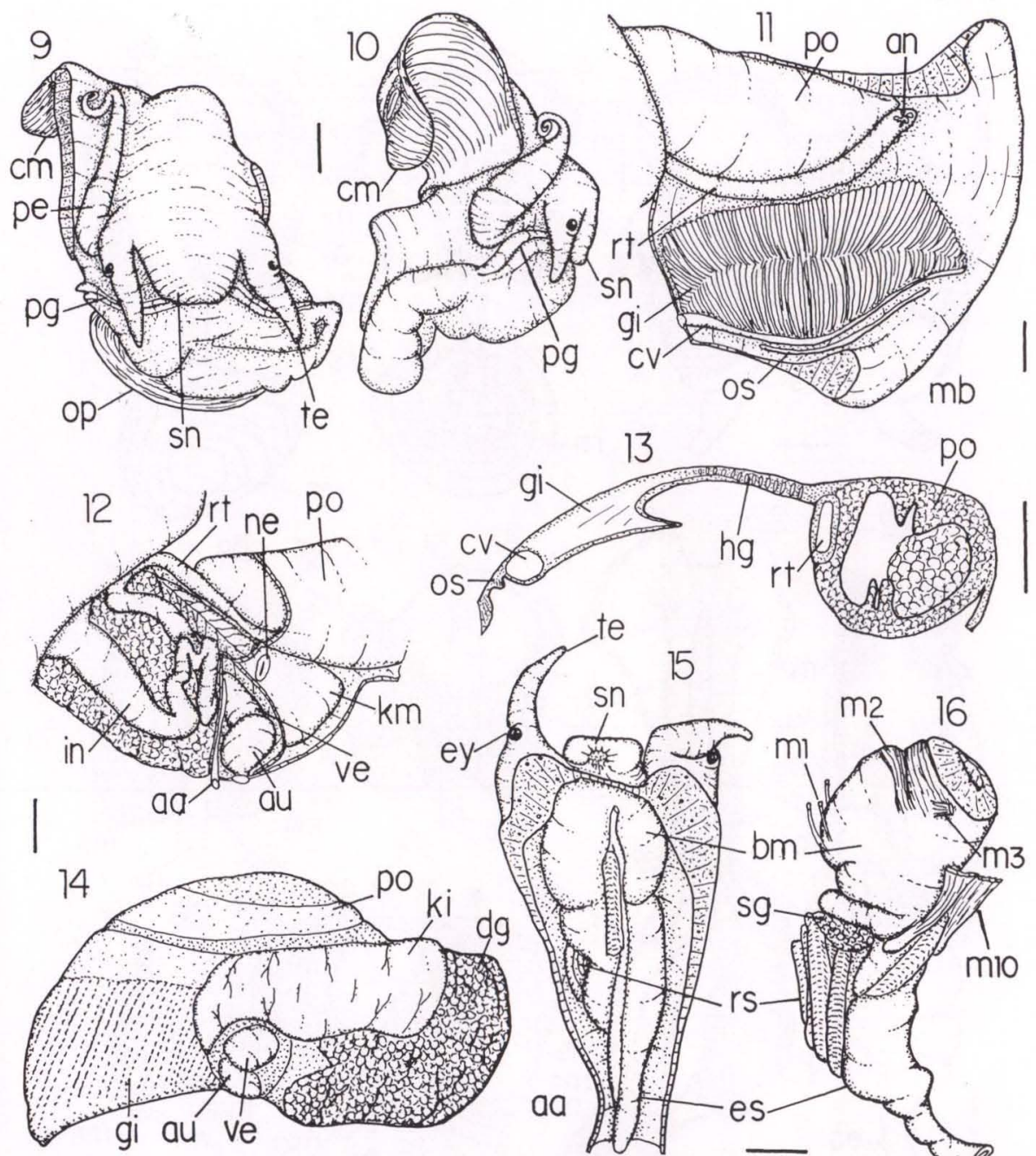

ad

Figs 9-16. Littorina flava anatomy. (9) Head-foot of male, frontal view; (10) same, lateral-right view; (11) pallial cavity of female, vental-inner view; (12) posterior limit of pallial cavity and anterior region of visceral mass with digestive gland and gonad partially removed, heart and kidney also exposed; (13) transversal section in middle region of pallial cavity roof of female; (14) kidney and pericardium region and adjacent areas, dorsal-outer view; (15) head and cephalic haemocoel, ventral view, foot removed; (16) anterior region of digestive system, lateral-right view. Scales $=1 \mathrm{~mm}$.

inconspicuous. Rectum narrow, running left margin of pallial gonoducts. Anus siphoned, posterior from mantle border. Pallial gonoducts broad and long, running right margin of pallial cavity, broader in female. Pallial gonoducts described bellow.

Circulatory and excretory systems (Figs 12,14). Heart sited behind left-posterior limit of pallial cavity; auricle anterior and at left of ventricle. Pericardium limits: kidney and pallial cavity anteriorly; digestive gland posteriorly; mantle 


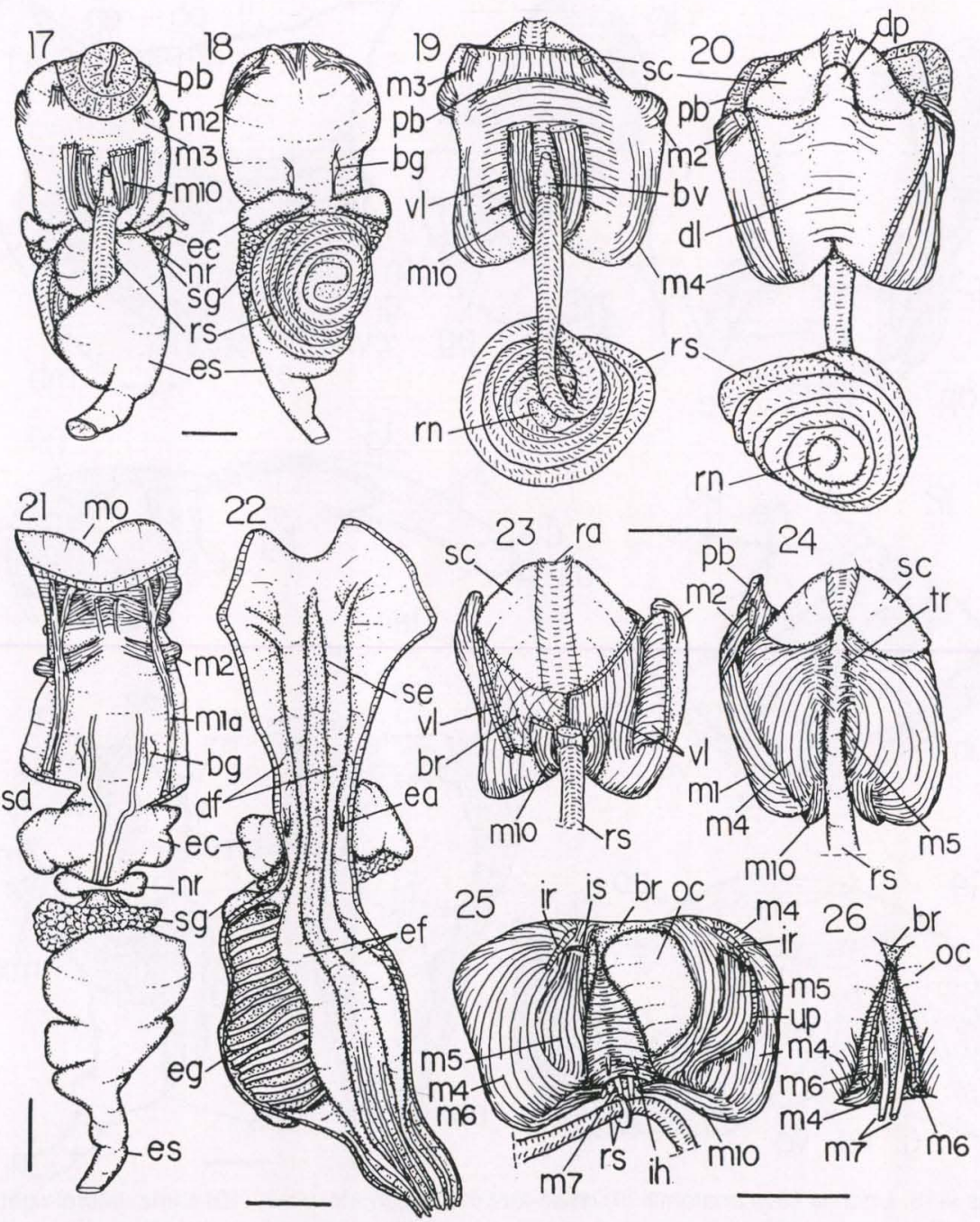

Figs 17-26. Littorina flava anatomy. (17) Anterior region of digestive system, ventral view; (18) same, dorsal view; (19) odontophore and radular sac extracted from buccal mass, ventral view; (20) same, dorsal view; (21) buccal mass and esophagus with odontophore extracted, dorsal-outer view; (22) same, ventral-inner view, esophagus opened longitudinally, inner surface exposed; (23) odontophore with first layer of muscles and membranes removed, ventral view; (24) same, dorsal view; (25) odontophore with radula and subradular cartilage removed, dorsal view, right side deflected to show inner region, left side as in situ; (26) detail of preceding structure with horizontal muscle cut antero-posteriorly to expose inner-dorsal surface of subradular membrane. Scales $=1 \mathrm{~mm}$.

dorsally. Aortas run in posterior surface, attached to membrane surrounding anterior region of digestive gland. Kidney with about 1/6 whorl in length, narrow, sited as middle and right posterior limit of pallial cavity; about half within visceral mass 
preceding rectum, and half exposed in pallial cavity. Renal tissue massive, yellowish. Nephrostome a small slit in right region of membrane between kidney and pallial cavity.

Digestive system (Figs 15-27). Mouth in anterior-ventral region of snout, longitudinal, thickly muscular (Fig. 15). Buccal mass posterior to snout, within head. Jaws missing, but a pair of jaw-pad-like structures found in local where jaws would stay (Fig. 22). A pair of broad folds begins in this local and runs longitudinally in inner surface of dorsal buccal mass wall, in direction to esophagus (Fig. 22). Salivary gland ducts open in middle-inner margin of these folds. Muscles of buccal mass and odontophore: $\mathrm{m} 1$ ) jugal muscles: several small muscle fibers around entire buccal mass, connecting it to inner surface of snout and head haemocoel, more concentrated near median line in both dorsal and ventral surfaces (Figs 16, 19, 20, 21, 24); a pair of jugal muscles outstanding (Fig. 21: mla), origin in dorsal region of mouth, insertion in posterior dorsal surface of buccal mass; m2) pair of large antero-dorsal compressor of buccal mass, origin part in dorsal peribuccal region (near median line), and part in adjacent region of dorsal buccal mass wall; insertion in lateral region of buccal mass (Figs 16-24); m3) pair of small and short ventral dilator of buccal mass, origin in ventral region of peribuccal wall, insertion in ventral-anterior region of buccal mass (Figs 16, 17, 19); dl) dorsal layer of transversal muscular fibers (Fig. 20), inserted in dorsal-lateral region of odontophore, separates it from esophageal region of buccal mass; presence of anterior projection covering part of radula (Fig. 20: dp); vl) ventral layer of muscular fibers (Figs 19, 23 ), inserted in lateral-ventral region of odontophore; outer layer of transversal fibers; inner layer of longitudinal fibers with origin in ventral region of mouth and insertion in posterior-ventral region of odontophore; $\mathrm{m} 4$ ) pair of lateral compressor tensor of radula (Figs 23-26), origin attached to anterior and dorsal region of cartilages, surrounding dorsally each cartilage, keep free only median and posterior surfaces of cartilages and insertion of peribuccal muscles; in ventral and anterior surfaces of each $\mathrm{m} 4$ thin, but strong subradular membrane inserts (Figs 25, 26: br), this membrane attaches in subradular cartilage; $\mathrm{m} 4$ also presents several small fibers inserted in a tissue covering dorsally radular ribbon (Fig. 24: tr); m5) pair of middle dorsal tensor of radula (Figs 24, 25), origin in dorsal and median surface of m4, insertion in middle-dorsal region of subradular cartilage, in level and bellow of $\mathrm{m} 4$ insertion in tissue on radula (tr); m6) horizontal muscle (Figs 25, 26), short and broad, insertion in ventral-lateral region of each cartilage; $\mathrm{m} 7$ ) narrow pair of posterior-ventral tensor of radula (Figs 25,26 ), origin as part of pair $\mathrm{m} 4$ in they ventral-posterior-median region, runs close subradular membrane, insertion in radular ribbon in base of radular sac; in this region $\mathrm{m} 7$ bears a hollow diverticulum, a blood sinus connected to anterior aorta (Fig. 19: bv); m10) pair of large posterior protractor of odontophore (Figs 19, 23, 25), origin in ventral anterior region of mouth, insertion in median-posterior-dorsal region of odontophore, attached to $\mathrm{m} 4$, close radular ribbon. Radular sac with some fibrotic ligament in inner (dorsal) surface of horizontal muscle (Fig. 25: ih). Radula very long, covered by thin transparent radular sac; cross left side of odontophore and coils in dorsal region, posterior to buccal mass, in 6-7 somewhat planispiral whorls (Figs 16-20). Radular 


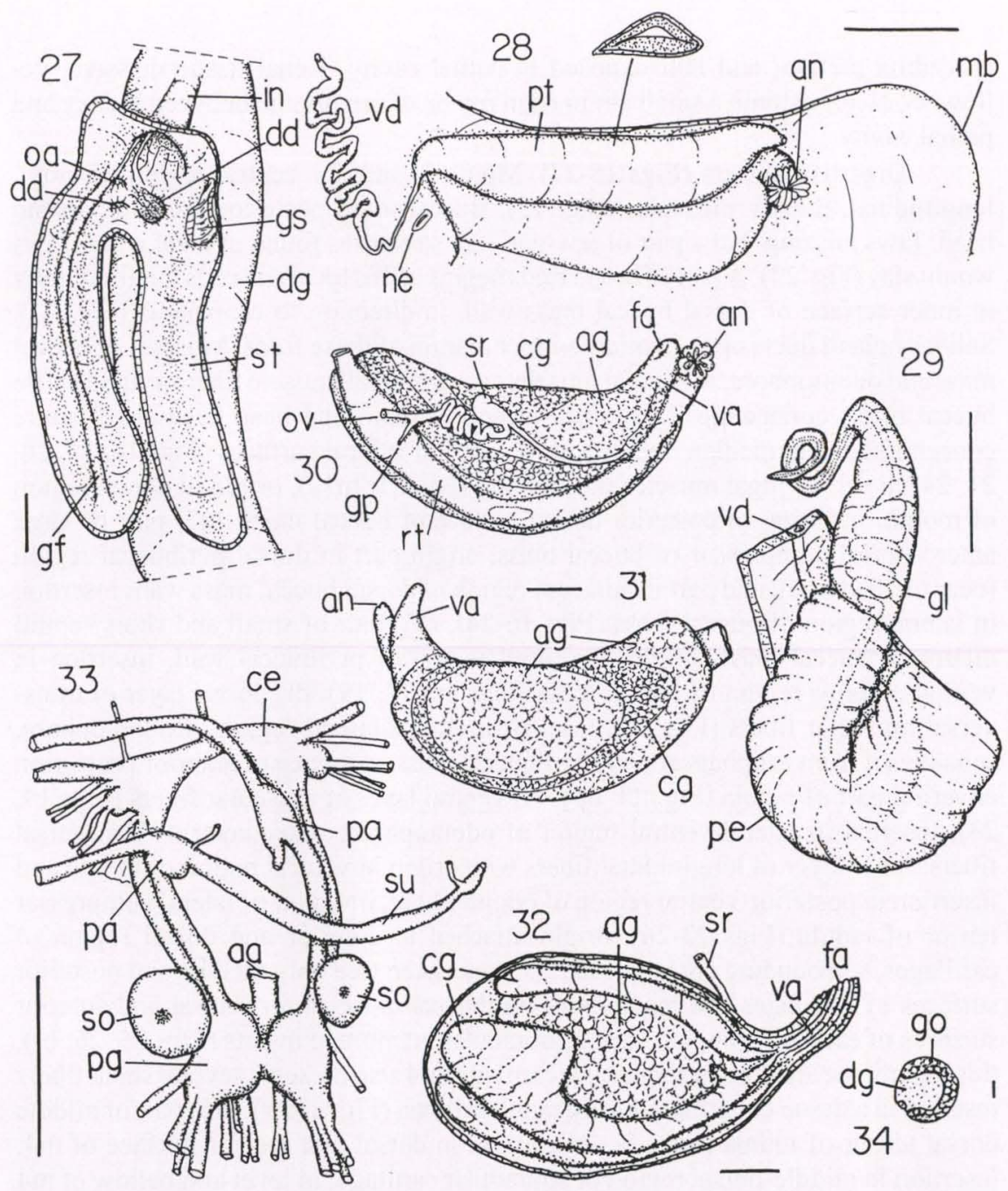

Figs 27-34. Littorina flava anatomy. (27) Stomach, outer-dorsal view, dorsal wall partially removed and deflected to show its inner surface; (28) detail of middle and anterior (pallial) regions of male spermoduct and right side of pallial cavity, inner-ventral view, with a detail of a transversal cut in middle region of prostate; (29) penis, frontal view, inner spermoduct seen by transparency; (30) pallial oviduct and rectum, ventral view; (31) same, dorsal-outer view; (32) same opened longitudinally in level of rectum, ventral view, albumen gland partially removed; (33) removed central nervous system (nerve ring), esophagus extracted, ventral view; (34) detail of transversal cut of anterior region of digestive gland and gonad, just posterior to stomach, columella in left side. Scales $=1 \mathrm{~mm}$.

nucleus sited in center of whorls and irrigated by a well developed branch of anterior aorta. No muscular fibers between radular sac and adjacent structures detectable. Radula (Figs 6-8): rachidian tooth long, with five cusps being central cusp very 
larger and with somewhat rounded apex (Fig. 8); lateral tooth broad, with a rounded terminal cut-edge, edged in each side by two small cusps, inner pair of cusps larger than outer pair; marginal teeth long, with four sharp terminal cusps each, sometimes with a fifth cusp incipient; inner marginal tooth differs from outer marginal tooth by a large, rounded and plane region in its outer terminal margin. Terminal cuspidate region of lateral and inner marginal teeth similar in an overview (Fig. 6), note in this figure that between two rachidian appears to have two rows of lateral elements. Pair of buccal ganglion relatively small, sited in dorsal-posterior region of buccal mass at short distance from median line (Fig. 21). Pair of esophageal crops posterior to buccal mass and anterior to nerve ring (Figs 21, 22); each crop hollow, with smooth inner surface, thin walled, very variable in form, in size and rarely symmetric; each crop opens to esophagus lateral-dorsally by a narrow orifice. Salivary glands an homogeneous glandular mass dorsal to nerve ring (Figs 16-18, 21, 22), compressed anteriorly by buccal mass and pouches, and posteriorly by esophagus and radular sac; pair of salivary ducts running attached to dorsal surface of esophagus near median line (Fig. 21), passing through nerve ring, open in dorsal wall of buccal mass as above described. Anterior esophagus, beyond orifices of esophageal crops, with only a pair of narrow, longitudinal, dorsal folds (Fig. 22: eg). Middle esophagus very broad; pair of folds of anterior esophagus becoming gradually broader and of ventral position; between both folds a smooth and somewhat broad area, some narrow longitudinal folds gradually appearing in its posterior third; in opposite side of folds a broad glandular pouch with successive, uniform, transversal folds (Fig. 22). Posterior esophagus a tube with narrow, longitudinal, somewhat uniform folds. Stomach narrow and very long - about half whorl in length; sited behind pallial cavity (Fig. 27). Esophagus opens in left-anterior region, edged at right by a fold which runs longitudinally middle region of dorsal gastric wall. Two ducts to digestive gland, both broad and ample, sited anterior to esophagus aperture (Fig. 27: dd); lateral duct runs ventrally almost perpendicular to stomach axis; inner-median duct runs to posterior region of digestive gland. Gastric shield developed, sited in right-anterior region of stomach, in level of esophagus aperture. Posterior $3 / 4$ of stomach a single sac without differentiable structures except above cited longitudinal fold (Fig. 27). Intestine aperture very ample, sited in anterior limit of stomach, bears a pair of very narrow typhlosoles in left side, which faint gradually (Figs 12, 27). Style sac not differentiated. Digestive gland pale cream in color, begins anteriorly to stomach, occupies entire ventral surface of stomach and runs about 1.5 whorls posterior to it. Intestine somewhat broad, runs initially in left region of anterior extremity of visceral mass, immerse in digestive gland (Fig. 12); near pericardium towards right, near kidney presents a small " $\mathrm{M}$ " shaped loop and towards left; newly near pericardium presents other loop and runs by anterior-dorsal extremity of visceral mass in posterior-right direction, lying kidney (but not passing through it). In right posterior extremity of pallial cavity emerges; rectum and anus above described.

Genital system. Male. Testis surround externally entire length of digestive gland (Fig. 34). Vas deferens runs close columella, a narrow, thick walled, sinuous tube (Fig. 28); posterior to pallial cavity become broader and greatly sinuous; near 
kidney suddenly narrows by a short distance and emerges to pallial cavity between rectum and right margin of this cavity. Prostate entirely closed, broad, thick glandular walled (Fig. 28), pale cream in color, occupying about entire length of pallial spermoduct. In region posterior to anus suddenly narrows and penetrates in right side of head tegument until penis base (Fig. 29). Penis long, inserted laterallyright in head (Figs 9, 10). Basal half of penis broader, curved to posterior (Fig. 29); spermoduct runs in this region near inner margin. Apical half of penis preceded by a superficial constriction, differentiating a glandiform structure; basal region of glandiform structure broader and with spermoduct intensely coiled, afterwards narrows gradually, spermoduct become simple (Fig. 29). Penis apex very narrow, in such tip spermoduct opens.

Female. Visceral region of female genital system similar to that of male except in being less sinuous. Oviduct emerges in middle region of posterior limit of pallial cavity as a very narrow duct; a narrow gono-pericardial duct present (Fig. 30 ). Oviduct runs to middle-ventral region of a very broad pallial oviduct, in this region coils and inserts in anterior extremity of a sac-like, small receptaculum seminis (Fig. 30); duct of receptaculum begins at right of oviduct insertion, runs ventral and anteriorly and inserts in left-anterior region of pallial oviduct. Pallial oviduct with albumen gland as central structure (Figs 30-32), white, covered by a thin membrane (Fig. 13). Capsule gland yellow, with two branches surrounding albumen gland (Figs 31, 32); right branch broader in posterior extremity; both branches with a deep central furrow in entire lenght. Between both branches of capsule gland, and in opposite side of albumen gland, a furrow running close external membrane of pallial oviduct (Fig. 32), in its face where rectum attaches. Duct of receptaculum opens in anterior third part of this furrow. This furrow continuities beyond anterior limit of capsule gland as a narrow vaginal tube, with inner surface presenting longitudinal, low folds (Fig. 32); vaginal tube with about $1 / 4$ of length of remainder pallial oviduct. Female pore subterminal and turned to right, posterior to anus (Figs 11,30).

Nervous system (Fig. 33). Circum-esophageal ganglia typical caenogastropod, epiathroid, with proportionally long connective between cerebral ganglia. Statocysts with single, large statolith each. Buccal ganglia described above.

Habitat. Supratidal species, generally in euryaline environment, sometimes are found in estuarine environment.

Distribution. At moment south Caribbean and entire Brazilian coasts. Specimens from other regions are still under analysis.

Measurements. MZSP 24886: 20.8 by 14.4; 19.5 by 14.0; MZSP $24859: 14.6$ by 11.1 .

Material examined. VENEZUELA, Nova Esparta: Margarita Island (La Isleta, EI Yaque beach), 1 specimen, MZSP 28390, 7/II/1995, Simone leg.. BRAZIL, Pará: Salinópolis, 62 specimens, MZSP 24847, 15/III/1969, H. Faiha leg.; Pernambuco: Itamaracá Island, $7^{\circ} 55^{\prime} \mathrm{S} 34^{\circ} 80^{\prime} \mathrm{W}, 11$ specimens, MZSP 24865, 8/VIII/1968; Bahia: 17 specimens, MZSP 8383, VI/1896, Bicego leg.; Ilhéus, 5 specimens, MZSP 24837, IV/1919, Garbe leg.; Porto Seguro (Vermelha beach), 34 specimens, MZSP 28308, V/95, Neyde Simone leg.; Rio de Janeiro (Ilha Grande, Furado 
beach), 11 specimens, MZSP 24856, 22/VII/1966); Angra dos Reis (Monsuaba beach) 84 specimens, MZSP 24859, 25/VII/1966; São Paulo: Ubatuba (Enseada do Lamberte), 60 specimens, MZSP 28295, 25/IX/1975, C.A. Zavaglia \& F.A. Sampaio leg.; (Queimada Grande Island, 24\%29'S $46^{\circ} 41^{\prime}$ 'W), 3 specimens, MZSP 24885, 4-8/VIII/1969, P. Biasi leg. .

\section{DISCUSSION}

The shell characters of $L$. flava have considerable degree of variation. The color are generally homogeneous pale cream (Figs 1,2), but dark brown, sparse spots can occur (Figs 3,4), also purple spot near shell apex. The sculpture generally is uniform spiral cords, but sometimes one of them (or more) can outstanding, becoming similar to a small carina; this can vary in whorls of a same shell. The considerable shell variation of the littorinids, which sometimes confuses the identification, is a known fact (Boulding et al. 1993).

In contrast with shell characters, the soft part characters present a little degree of variation. The penis of $L$. flava differs greatly from other Western Atlantic Littorina species (MARCUS \& MARCUS 1963) in lacking annex glands and by development of the glandiform structure. The penis of the littorinids indubitably present important characters for systematics, and generally is one of the goals in revisions (PONDER 1976; BANDEL \& KADOLSKY 1982; REID 1989). On the other hand, analysis of other organs of soft parts are very scanty, which precludes any detailed comparison. A more extensive anatomical description is found in FRETTER \& GRAHAM (1962) on European L. littorea, from which L. flava differs anatomically mainly in having hypobranchial gland less developed, shorter osphradium, pallial and penis spermoduct closed, absence of penis glands, absence of retractor muscles of radular sac, gastric sorting areas inconspicuous, kidney tissue not so folded, bursa copulatrix lacking and receptaculum seminis more anterior.

The pallial oviduct appears to be also valuable for species comparison. The pallial oviduct of L. flava differs greatly from those of Pacific species (REID \& GoLIKOV 1991; REID et al. 1991), mainly in lacking septate jelly gland, in having the bursa copulatrix sited in middle region of pallial oviduct (and not anterior), and a well developed vaginal tube.

The odontophore of $L$. flava is peculiar in lacking muscles in both extremities of the radular ribbon. In this way, the odontophore muscles probably do not move the radula in a coming-and-going movement (gliding on cartilages), but so may stick it and the entire odontophore may work as an eraser. This type of odontophore was observed in Cerithioidea and Hydrobioidea (person. obs.), aim of other in press studies (this is the reason for some numbers are omitted in numeration of odontophore muscles), which will permit future suggestions of homologies. Although the name of each odontophore muscle is given in description, these obviously may change with further studies on comparative morphology (on going) and on physiology. The L. flava odontophore, however, differs from those of upper cited "basal" Caenogastropoda, in having a up-side-down disposition of several muscles, more evident by ventral site of horizontal muscle (m6), which normally is dorsal. 
The resistance of the littorinids to long periods exposed to air is a notable fact. Under the light of the results of YIPP \& CAREFOOT (1988) research, L. flava has a similar fashion of pallial organs, gill in particular, of Nodilittorina spp., species with broad gill filaments and high degree of resistance in aerial environment. It is interesting to note that the littorinids do not present any special structure or arrangement of pallial organs, being anatomically very similar to normal standard of the caenogastropods, except for the region of each gill filament where cilia is lacking.

\section{REFERENCES}

Aввотт, R.T. 1974. American seashells. New York, Van Nostrand Reinhold Company, $2^{\text {nd }}$ ed., $663 \mathrm{p}$.

BANDEL, K. 1974. Studies on Littorinidae from the Atlantic. Veliger, Berkeley, 17 (2): $92-114$.

BANDEL, K. \& D. KADOLSKY. 1982. Western Atlantic species of Nodilittorina (Gastropoda: Prosobranchia): comparative morphology and its functional, ecological, phylogenetic and taxonomic implications. Veliger, Berkeley, 25 (1): $1-42$.

BequaerT, J.C. 1943. The genus Littorina in the Western Atlantic. Johnsonia, Cambridge, 1 (7): 1-28.

Boulding, E.G.; J. BuCKLAND-NiCKs \& K.L.V. ALsTYNE. 1993. Morphological and allozyme variation in Littorina sitkana and related Littorina species from the Northeastern Pacific. Veliger, Berkeley, 36 (1): 43-68.

FRETTER, V. \& A. GRAHAM. 1962. The anatomy of Littorina to illustrate prosobranch organization, p.14-48. In: V. FRETTER \& A. GRAHAM (Eds). British prosobranch molluscs. London, Ray Society, 755p.

FURTADO-OGAWA, F. 1970. Contribuição ao conhecimento da fauna malacológica intertidal de substratos duros no Nordeste Brasileiro. Arq. Ciências Mar, Fortaleza, 10 (2): 193-196.

KING, P.P. \& W.J. BRODERIP. 1832. Description of the Cirrhipedia, Conchifera and Mollusca, in a collection formed by the officers of H.M.S. Adventure and Beagle employed between the years 1826 and 1830 in surveying the southern coast of South America, including the Straits of Magalhaens and the coast of Tierra del Fuego. Zool. Jour., London, 5: 332-349.

MARCUS, E. \& E.B.R. MARCUS. 1963. Mesogastropoden von der küste São Paulos. Abhandlungen der Mathematisch-Naturwissenschaftlichen Klasse 1: 1105.

MATthews, H.R. 1968. Notas sobre a família Littorinidae no Nordeste brasileiro (Mollusca: Gastropoda). Arq. Est. Biol. Mar. Univ. Fed. Ceará 8 (2): 183-186. Morretes, F.L. 1949. Ensaio de catálogo dos moluscos do Brasil. Arq. Mus. Paranaense, Curitiba, 7: 1-216.

OliveirA, M.P.; G.J.R. REZENDE \& G.A. CASTRO. 1981. Catálogo dos moluscos da Universidade Federal de Juiz de Fora. MEC, Universidade Federal Juiz de Fora, 520p.

ORBIGNY, A. 1834-1847. Voyage dans l'Amérique méridionale. 5(3): mollus- 
ques. Paris, $758 \mathrm{p}$.

PONDER, W.F. 1976. Three species of Littorinidae from Southern Australia. Malacological Review, Whitmore Lake, 9: 105-114.

REID, D.G. 1989. Systematic revision of the recent species of Peasiella Nevill, 1885 (Gastropoda: Littorinidae), with notes on the fossil species. Nautilus, Washington, 103 (2): 43-69.

REID, D.G. \& A.N. GóliKov. 1991. Littorina naticoides, new species, with notes on the other smooth-shelled Littorina species from the Northwestern Pacific. Nautilus, Washington, 105 (1): 7-15.

REID, D.G.; N.I. ZASLAVSKAYA \& S.O. SERGIEVSKY. 1991. Littorina kasatka, a new species from the Kurile Island and Okhotsk Sea. Nautilus, Washington, 105 (1): 1-6.

Rios, E.C. 1970. Coastal Brazilian seashells. Rio Grande, Museu Oceanográfico de Rio Grande, 255p.

- 1975. Brazilian marine mollusks iconography. Rio Grande, Museu Oceanográfico de Rio Grande, 331p.

- 1985. Seashells of Brazil. Fundação Universidade de Rio Grande -Museu Oceanográfico. Rio Grande, 328 pp +102 pls.

- 1994. Seashells of Brazil. Rio Grande, Fundação Universidade de Rio Grande, Museu Oceanográfico, $2^{\text {nd }}$ ed., $368 \mathrm{p}$.

VERMEIJ, G.J.\& J.W. PORTER. 1971. Some characteristics of the dominant intertidal molluscs from rocky shores in Pernambuco, Brazil. Bull. Mar. Sc., Miami, 21: 440-454.

YIPP, M.W. \& T.H. CAREFOOT. 1988. Studies on distribution, degree of aerial exposure, and comparative interactions in four species of tropical intertidal gastropods. Veliger, Berkeley, 31 (1-2): 91-100.

Recebido em 11.XII.1997; aceito em 26.X. 1998. 